\title{
Pengaruh Metode Pemberian Tugas (Take Home) Terhadap Minat Belajar Anak Kelompok B Di Tk Dharma Wanita Gedangan Mojokerto
}

\author{
Indri Dwi Isnaini \\ $P G-P A U D$ \\ STKIP Bina Insan Mandiri \\ Telp. 082232967242 \\ E-mail: indridwi@stkipbim.ac.id
}

\begin{abstract}
ABSTRAK
Salah satu faktor eksternal yang mempengaruhi minat belajar anak adalah pemberian tugas rumah atau Pekerjaan Rumah (PR). Menurut Muijs, dkk (2008: 150) "Pekerjaan rumah dapat didefinisikan sebagai kegiatan di luar kelas yang merupakan perluasan dari tugas di kelas". Adapun tujuan dari penelitian ini untuk mengetahui pengaruh metode pemberian tugas terhadap minat belajar anak. Untuk menjawab masalah diatas, peneliti melakukan penelitian deskriptif kuantitatif. Penelitian ini dilaksanakan di Kelompok B TK Dharmawanita Gedangan Mojokerto tahun Ajaran 2016/2017. Subjek pada penelitian berjumlah 20 anak. Teknik pengumpulan data dilakukan melalui observasi, wawancara dan dokumentasi. Pengamatan sebelum diberi perlakuan rekapitulasinya diperoleh rata-rata, yaitu rata-rata $0 \%$ anak dalam kategori Sangat Tinggi (ST), 3,33\% anak dalam kategori Tinggi (T), 13,33\% anak dalam kategori Sedang (S), dan 83,33\% anak dalam kategori Rendah (R), pada aspek pengamatan ketertarikan anak, Perhatian anak dalam pembelajaran dan keterlibatan anak. Pengamatan setelah diberi perlakuan diperoleh rata-rata 35,28\% anak yang tergolong kategori Sangat Tinggi (ST), Selanjutnya untuk kategori Tinggi (T) diperoleh rata-rata 17,61\%. Untuk kategori Sedang (S) diperoleh rata-rata $20,28 \%$, dan untuk kategori Rendah (R) diperoleh rata-rata 26,83\%, pada aspek pengamatan ketertarikan anak, Perhatian anak dalam pembelajaran dan keterlibatan anak.
\end{abstract}

\section{Kata kunci : Metode Pemberian Tugas (Take Home), Minat Belajar Anak}

\begin{abstract}
One of the external factors that affect the child's interest in learning is the assignment of homework or homework. According to Muijs, et al (2008: 150) "Homework can be defined as an out-of-class activity that is an extension of classroom work". The purpose of this study to determine the effect of methods of assignment to the interests of learning children. To answer the above problems, researchers conducted a quantitative descriptive study. This research was conducted in Group B TK Dharmawanita Gedangan Mojokerto academic year 2016/2017. Subjects in the study amounted to 20 children. Technique of data collection is done through observation, interview and documentation. Observations before the recapitulation treatment were obtained on average, ie $0 \%$ of children in the Very High (ST) category, 3.33\% of children in the High (T) category, $13.33 \%$ of children in Medium (S) category, and $83.33 \%$ of children in the
\end{abstract}


Low category $(\mathrm{R})$, on the observation aspect of child's interest, Child's attention in learning and child involvement. Observations after treatment were obtained an average of $35.28 \%$ of children belonging to the category Very High (ST), Next to the category High (T) obtained an average of $17.61 \%$. In the Medium category (S), the mean is $20.28 \%$, and for the Low category (R), the average is $26.83 \%$, the observation aspect of the child's interest, the child's attention in learning and the involvement of the child.

Keywords: Method of Giving Task (Take Home), Interest Learning Children

\section{A. Pendahuluan.}

Era globalisasi menuntut sumber daya manusia untuk memiliki kemampuan agar dapat bersaing di dunia internasional. Sumber daya manusia yang mempunyai kemampuan untuk bersaing di dunia internasional tentu tidak begitu saja ada tetapi membutuhkan banyak hal yang berperan dalam proses pembentukan sumber daya manusia tersebut. Salah satu hal yang berperan besar dalam membentuk sumber daya manusia menjadi sumber daya yang handal, cerdas, mempunyai karakter dan mampu bersaing di dunia internasional adalah melalui pendidikan.

Pada hakikatnya, pendidikan bagi manusia itu sendiri berlangsung sepanjang hayat sejak dia dilahirkan sampai dia meninggal dunia. Pendidikan adalah suatu usaha yang dilakukan secara sadar dan sengaja untuk mengubah tingkah laku manusia baik secara individu maupun kelompok untuk mendewasakan manusia melalui upaya pengajaran dan pelatihan (Sugihartono dkk, 2012: 3). ${ }^{1}$ Proses pembentukan SDM yang handal, cerdas, berahlak dan berkarakter melalui pendidikan sesuai dengan pengertian pendidikan yang ada di Indonesia seperti tercantum dalam UU No. 20 Tahun 2003 tentang Sistem Pendidikan Nasional yang berbunyi: Pendidikan adalah usaha sadar dan terencana untuk mewujudkan suasana belajar dan proses pembelajaran agar peserta didik secara aktif mengembangkan potensi dirinya untuk memiliki kekuatan spiritual keagamaan, pengendalian diri, kepribadian, kecerdasan, akhlak mulia, serta keterampilan yang diperlukan dirinya, masyarakat, bangsa dan negara.

Pendidikan dilaksanakan melalui tiga jalur yaitu pendidikan formal, pendidikan nonformal, dan pendidikan informal. Pendidikan formal dalam hal ini diadakan oleh lembaga yang bernama sekolah. Sekolah merupakan tempat anak untuk menuntut ilmu

\footnotetext{
${ }^{1}$ Sugihartono, dkk. Psikologi Pendidikan. (Yogyakarta: UNY Press), 3.
} 
dan pengetahuan yang akan berguna bagi kehidupannya di masa yang akan datang. Keberhasilan sekolah dalam menyelenggarakan pendidikan dapat dilihat dari berbagai hal, salah satunya adalah dalam hal minat belajar anak. Minat belajar adalah suatu bukti usaha anak dalam melakukan kegiatan belajarnya. Minat merupakan kemampuan seseorang untuk memberikan perhati-an terhadap suatu hal yang disertai dengan rasa senang dan dilakukan penuh kesadaran. Anak yang menaruh minat pada suatu mata pelajaran, perhatiannya akan tinggi dan minatnya berfungsi sebagai pendorong kuat untuk terlibat secara aktif dalam kegiatan belajar mengajar pada pelajaran tersebut.

Minat belajar anak secara garis besar dipengaruhi oleh dua faktor, yaitu faktor internal dan faktor eksternal. Faktor-faktor internal yang berasal dari dalam diri anak meliputi: faktor jasmaniah (terdiri dari faktor kesehatan dan cacat tubuh), faktor psikologi (terdiri atas intelegensi, perhatian, minat, bakat, motivasi, persepsi, kematangan dan kesiapan) dan faktor kelelahan. Sedangkan faktor eksternal yang berasal dari luar diri anak meliputi: faktor keluarga yaitu cara orang tua mendidik, relasi antar anggota keluarga, suasana rumah, keadaan ekonomi keluarga, pengertian orang tua, latar belakang kebudayaan, faktor sekolah yaitu metode mengajar, kurikulum, hubungan guru dengan anak, hubungan anak dengan anak, disiplin sekolah, media pembelajaran, waktu sekolah, keadaan gedung, metode belajar dan tugas rumah; faktor masyarakat yaitu kegiatan anak dalam masyarakat, media, teman bergaul, dan bentuk kehidupan masyarakat.

Salah satu faktor eksternal yang mempengaruhi minat belajar anak adalah pemberian tugas rumah atau Pekerjaan Rumah (PR). Menurut Muijs, dkk (2008: 150) "Pekerjaan rumah dapat didefinisikan sebagai kegiatan di luar kelas yang merupakan perluasan dari tugas di kelas". ${ }^{2}$ Pekerjaan Rumah merupakan salah satu aspek mengajar yang paling luas digunakan oleh guru. Di sisi lain, anak seringkali menganggap Pekerjaan Rumah sebagai beban mereka. Pekerjaan Rumah dapat dirancang dengan maksud meningkatkan minat belajar anak, hal ini dikarenakan dengan pemberian PR maka intensitas belajar anak akan meningkat dan tingkat penguasaan materi anak bertambah dengan diharuskannya anak untuk mengerjakan tugas yang telah diberikan oleh guru.

\footnotetext{
${ }^{2}$ Muijs, Daniel, \& Reynolds, David. Effective teaching: Teori dan Aplikasi. (Yogyakarta: Pustaka Pelajar), 150.
} 
Faktor internal yang berpengaruh pada minat belajarsalah satunya adalah minat belajar. "Minat Belajar merupakan keinginan yang datang dari hati nurani untuk ikut serta dalam kegiatan belajar" (Suprijanto, 2007: 25). ${ }^{3}$ Dalam proses belajar, minat memegang peranan penting bagi prestasi belajar yang akan diperoleh anak. Seorang anak akan memperhatikan apa yang diterangkan oleh guru dan mengerjakan tugas yang diberikan jika dia mempunyai minat untuk belajar pada mata pelajaran tertentu. "Minat belajar yang besar cenderung menghasilkan prestasi yang tinggi, sebaliknya minat belajar kurang akan menghasilkan prestasi yang rendah" (Dalyono, 2005: 122). ${ }^{3}$

Semua sekolah termasuk TK Dharmawanita Kecamatan Kutorejo Mojokerto tentu bertujuan untuk dapat menyelenggarakan suatu pendidikan yang baik dan berhasil mencetak lulusan yang berkualitas. Keberhasilan sekolah dalam menyelenggarakan pendidikan dapat dilihat dari berbagai hal, salah satunya adalah dalam hal prestasi belajar yang diperoleh oleh anak. Prestasi belajar adalah suatu bukti keberhasilan belajar atau kemampuan seorang anak dalam melakukan kegiatan belajarnya sesuai dengan bobot yang dicapainya. Minat belajar seorang anak dapat menjadi gambaran berhasil tidaknya suatu proses pembelajaran yang telah dilakukan. Prestasi belajar dipengaruhi oleh proses belajar anak yang akan menentukan tingkat minat belajar anak.

Minat belajar anak secara garis besar dipengaruhi oleh dua faktor, yaitu faktor internal dan faktor eksternal. Faktor-faktor internal yang berasal dari dalam diri anak meliputi: faktor jasmaniah (terdiri dari faktor kesehatan dan cacat tubuh), faktor psikologi (terdiri atas intelegensi, perhatian, minat, bakat, motivasi, persepsi, kematangan dan kesiapan) dan faktor kelelahan. Sedangkan faktor eksternal yang berasal dari luar diri anak meliputi: faktor keluarga yaitu cara orang tua mendidik, relasi antar anggota keluarga, suasana rumah, keadaan ekonomi keluarga, pengertian orang tua, latar belakang kebudayaan, faktor sekolah yaitu metode mengajar, kurikulum, hubungan guru dengan anak, hubungan anak dengan anak, disiplin sekolah, alat pelajaran, waktu sekolah,

\footnotetext{
${ }^{3}$ Suprijanto. Pendidikan Orang Dewasa: Dari Teori Hingga Aplikasi.(Jakarta: PT Bumi Aksara), 25

${ }^{4}$ Dalyono. Belajar dan Faktor-Faktor yang Mempengaruhinya. (Jakarta: PT Rineka Cipta), 122.
} 
keadaan gedung, metode belajar dan tugas rumah; faktor masyarakat yaitu kegiatan anak dalam masyarakat, media, teman bergaul, dan bentuk kehidupan masyarakat.

Pada kenyataanya peneliti melihat anak kelompok B di TK Dharma Wanita Gedangan nilainya begitu susah sekali meningkat. Minat belajar antara anak yang satu dengan anak yang lainnya belum tentu sama terhadap satu pelajaran tertentu. Maka dari itu peneliti menetapkan untuk menggunakan metode dengan memberikan tugas rumah (take home) sebagai alat untuk mengetahui minat belajar anak kelompok B di TK Dharma Wanita Gedangan Mojokerto.

\section{B. PEMBAHASAN}

Jenis penelitian yang digunakan dalam penelitian ini ialah penelitian deskriptif, yang datanya diambil dari lapangan, yang bersifat kuantitatif. Variable dalam penelitian yaitu variable bebas (metode take home) dan variable terikat (minat belajar anak). Secara sederhana desain penelitian ini dapat digambarkan sebagai berikut :

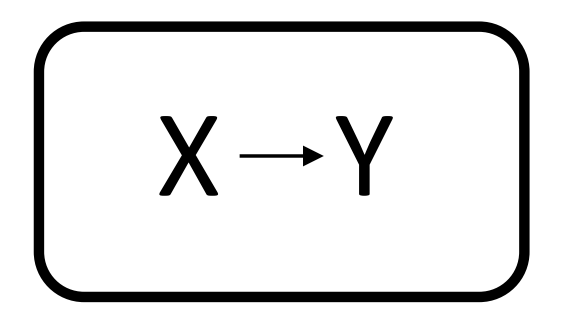

$$
\text { Keterangan : } \begin{aligned}
\mathrm{X} & =\text { Metode Take Home } \\
\mathrm{Y} & =\text { Minat Belajar } \\
\longrightarrow & =\text { Pengaruh }
\end{aligned}
$$

Subjek penelitian adalah kelompok B TK TK Dharma Wanita Gedangan yang berjumlah 20 anak. Untuk mengumpulkan sejumlah data di lapangan digunakan teknik pengumpulan data teknik observasi yang dilakukan untuk mendapatkan gambaran yang lengkap tentang pengaruh metode eksperimen sains sederhana terhadap minat belajar anak, khususnya untuk melihat rasa ketertarikan anak, perhatian dalam pembelajran dan Keterlibatan anak pada proses belajar dan pembelajaran.

Teknik dokumentasi dilakukan untuk memperoleh hasil penelitian yang menggambarkan situasi anak pada saat anak pembelajaran. Teknik wawancara dilakukuan untuk menggambarkan tentang minat belajar anak sebelum dan setelah diterapkan metode eksperimen sains sederhana. Data yang terkumpul diolah dengan menggunakan teknik persentase, kemudian hasil olahan dianalisis secara deskriptif, 
rumus menurut Sugiyono (2009:40), ${ }^{4}$ untuk menganalisis data yang dikumpulkan secara persentase, yaitu:

$$
\mathrm{P}=\frac{f}{N} x 100 \%
$$

Keterangan:

$\mathrm{P}=$ Presentase

$\mathrm{F}=$ Frekuensi

$\mathrm{N}=$ Banyak Individu

Tabel 1. Indikator minat belajar anak

\begin{tabular}{|c|l|l|c|}
\hline No & \multicolumn{1}{|c|}{ ASPEK } & \multicolumn{1}{|c|}{ INDIKATOR } & $\begin{array}{c}\text { JENIS } \\
\text { INSTRUMEN }\end{array}$ \\
\hline 1 & Ketertarikan & $\begin{array}{l}\text { 1.1 Adanya kemauan untuk } \\
\text { menyelesaikan tugas }\end{array}$ & Observasi \\
\cline { 3 - 4 } & & $\begin{array}{l}\text { 1.2 Menunjukkan sikap ketertarikan } \\
\text { dalam kegiatan pembelajaran }\end{array}$ & Observasi \\
\hline 2. & $\begin{array}{l}\text { Perhatian dalam } \\
\text { pembelajaran }\end{array}$ & $\begin{array}{l}\text { 2.1 Menunjukkan konsentrasi dalam } \\
\text { pembelajaran }\end{array}$ & Observasi \\
\cline { 3 - 4 } & $\begin{array}{l}\text { 2.2 Menunjukkan ketelitian dalam setiap } \\
\text { tugas }\end{array}$ & Observasi \\
\cline { 3 - 4 } & $\begin{array}{l}\text { 2.3 Memiliki semangat dalam setiap } \\
\text { pembelajaran }\end{array}$ & Observasi \\
\hline 3. & Keterlibatan & $\begin{array}{l}\text { 3.1 Menunjukkan keaktifan dalam } \\
\text { mengikuti pembelajaran }\end{array}$ & Observasi \\
\cline { 3 - 4 } & $\begin{array}{l}\text { 3.2 Berusaha menyelesaikan tugas yang } \\
\text { diberikan }\end{array}$ & Observasi \\
\cline { 3 - 4 } & $\begin{array}{l}\text { 3.3 Memiliki kesungguhan dalam } \\
\text { menyelesaikan tugas yang diberikan guru }\end{array}$ & Observasi \\
\hline
\end{tabular}

\section{Hasil Pengamatan}

Data hasil pengamatan yang diperoleh dilapangan sebelum diberi perlakuan dan setelah diberi perlakuan akan disajikan pada tabel dibawah ini :

Tabel 2 Rekapitulasi hasil pengamatan sebelum diberi perlakuan

${ }^{4}$ Sugiyono. Penelitian Pendidikan Pendekatan Kuantitati, Kualitatif, dan R\&D. (Bandung: Alfabeta) 40 


\begin{tabular}{|c|c|c|c|c|c|c|c|c|}
\hline \multirow{3}{*}{ No } & \multirow{3}{*}{ Kategori } & \multicolumn{6}{|c|}{ Aspek yang diamati } & \multirow{3}{*}{$\begin{array}{c}\text { Rata-rata } \\
(\%)\end{array}$} \\
\hline & & \multicolumn{2}{|c|}{$\begin{array}{c}\text { Aspek } \\
\text { Ketertarikan }\end{array}$} & \multicolumn{2}{|c|}{$\begin{array}{c}\text { Aspek } \\
\text { Perhatian } \\
\text { dalam } \\
\text { pembelajaran }\end{array}$} & \multicolumn{2}{|c|}{$\begin{array}{c}\text { Aspek } \\
\text { Keterlibatan }\end{array}$} & \\
\hline & & $\mathrm{f}$ & $\%$ & $\mathrm{f}$ & $\%$ & $\mathrm{f}$ & $\%$ & \\
\hline 1 & $\begin{array}{l}\text { Sangat Tinggi } \\
(\mathrm{ST})\end{array}$ & 0 & 0 & 0 & 0 & 0 & 0 & 0 \\
\hline 2 & Tinggi $(\mathrm{T})$ & 1 & 5 & 1 & 5 & 0 & 0 & 3,33 \\
\hline 3 & Sedang (S) & 3 & 15 & 2 & 10 & 3 & 15 & 13,33 \\
\hline 4 & Rendah (R) & 16 & 80 & 17 & 85 & 17 & 85 & 83,33 \\
\hline 5 & Jumlah & 20 & 100 & 20 & 100 & 20 & 100 & 99.99 \\
\hline
\end{tabular}

Berdasarkan tabel 1 hasil rekapitulasi pengamatan sebelum diberi perlakuan diatas dapat terlihat bahwa dari 20 orang anak di kelompok B TK Dharma Wanita Gedangan, Kutorejo, dalam aspek Ketertarikan Anak, terdapat 0 anak (0\%) kategori Sangat Tinggi dikarenakan belum ada anak yang tertarik dengan pembelajaran, ada 1 anak (5\%) kategori Tinggi dikarenakan terdapat hanya 1 anak yang mampu tertarik dalam proses belajar mengajar, 3 anak (15\%) kategori Sedang dikarenakan hanya 3 anak yang tertarik, dan 16 anak (80\%) dalam kategori Rendah dikarenakan terdapat 16 anak yang belum tertarik dengan pembelajaran.

Selanjutnya pada aspek Perhatian dalam pembelajaran Anak, terdapat belum ada anak $(0 \%)$ kategori Sangat Tinggi dikarenakan belum ada anak yang Perhatian dalam pembelajaran, ada 1 anak (5\%) kategori Tinggi dikarenakan terdapat 1 anak yang Perhatian dalam pembelajaran, 2 anak (10\%) kategori Sedang dikarenakan terdapat 2 anak yang Perhatian dalam pembelajaran, dan 17 anak (85\%) dalam kategori Rendah dikarenakan terdapat sebanyak 17 anak yang belum merasa Perhatian dalam pembelajaran.

Dan pada aspek Keterlibatan anak, terdapat belum ada anak (0\%) kategori Sangat Tinggi dikarenakan belum ada anak yang mau terlibat dalam pembelajaran, kemudian belum ada anak (0\%) kategori Tinggi dikarenakan belum ada anak yang mau terlibat melakukan kegiatan dalam pembelajaran, 3 anak (15\%) kategori Sedang dikarenakan terdapat 3 anak yang mau terlibat dalam pembelajaran, dan 17 anak (85\%) dalam kategori 
Rendah dikarenakan terdapat sebanyak 17 anak yang belum mau terlibat dalam pembelajaran.

Rekapitulasi hasil presentasi rata-rata pada semua aspek yang diamati, sebelum adanya tindakan yaitu terdapat 0\% dalam kategori Sangat Tinggi, 3,33\% dalam kategori tinggi, 13,33\% dalam kategori Sedang, dan terdapat 83,33\% dalam kategori Rendah.

\section{Tabel 3 Hasil rekapitulasi pengamatan setelah diberi perlakuan}

\begin{tabular}{|c|c|c|c|c|c|c|c|c|}
\hline \multirow{3}{*}{ No } & \multirow{3}{*}{ Kategori } & \multicolumn{6}{|c|}{ Aspek yang diamati } & \multirow{3}{*}{$\begin{array}{c}\text { Rata-rata } \\
(\%)\end{array}$} \\
\hline & & \multicolumn{2}{|c|}{$\begin{array}{c}\text { Aspek } \\
\text { Ketertarikan }\end{array}$} & \multicolumn{2}{|c|}{$\begin{array}{c}\text { Aspek } \\
\text { Perhatian } \\
\text { dalam } \\
\text { pembelajaran }\end{array}$} & \multicolumn{2}{|c|}{$\begin{array}{c}\text { Aspek } \\
\text { Keterlibatan }\end{array}$} & \\
\hline & & $\mathrm{f}$ & $\%$ & $\mathrm{f}$ & $\%$ & $\mathrm{f}$ & $\%$ & \\
\hline 1 & $\begin{array}{l}\text { Sangat Tinggi } \\
\text { (ST) }\end{array}$ & 6 & 30,83 & 8 & 40 & 7 & 35 & 35,28 \\
\hline 2 & Tinggi (T) & 3 & 16,67 & 4 & 19,17 & 3 & 17 & 17,61 \\
\hline 3 & Sedang (S) & 6 & 27,50 & 2 & 13,33 & 4 & 20 & 20,28 \\
\hline 4 & Rendah (R) & 5 & 25 & 6 & 27,50 & 6 & 28 & 26,83 \\
\hline 5 & Jumlah & 20 & 100 & 20 & 100 & 20 & 100 & 100 \\
\hline
\end{tabular}

Berdasarkan tabel 2 hasil rekapitulasi pengamatan setelah diberi perlakuan diatas dapat terlihat bahwa dari 20 orang anak di kelompok B TK Dharma Wanita Gedangan, setelah diberi perlakuan yaitu berupa pemberian tugas (Take home) dalam aspek Ketertarikan Anak, terdapat 6 anak (30,83\%) kategori Sangat Tinggi dikarenakan terdapat 6 anak yang mampu tertarik dalam pembelajaran, ada 3 anak (16,67\%) kategori Tinggi dikarenakan terdapat hanya 3 anak yang tertarik dalam pembelajaran, 6 anak $(27,50 \%)$ kategori Sedang dikarenakan terdapat 6 anak yang tertarik dalam pembelajaran, dan 5 anak (25\%) dalam kategori Rendah dikarenakan terdapat 5 anak yang tertarik dalam pembelajaran.

Selanjutnya pada aspek Perhatian dalam pembelajaran, terdapat 8 anak (40\%) kategori Sangat Tinggi dikarenakan terdapat 8 anak yang Perhatian dalam pembelajaran, ada 4 anak $(19,17 \%)$ kategori Tinggi dikarenakan terdapat 4 anak yang Perhatian dalam pembelajaran, 2 anak $(13,33 \%)$ kategori Sedang dikarenakan terdapat 2 anak yang Perhatian dalam pembelajaran, dan 6 anak (27,50\%) dalam kategori Rendah dikarenakan terdapat 6 anak yang belum merasa Perhatian dalam pembelajaran. 
Dan pada aspek Aspek Keterlibatan anak, terdapat sebanyak 7 anak (35\%) kategori Sangat Tinggi dikarenakan terdapat 7 anak yang mau terlibat dalam pembelajaran, kemudian ada 3 anak (17\%) kategori Tinggi dikarenakan terdapat 3 anak yang mau terlibat dalam pembelajaran, 4 anak (20\%) kategori Sedang dikarenakan terdapat 4 anak yang mau terlibat dalam pembelajaran, dan 6 anak (28\%) dalam kategori Rendah dikarenakan terdapat sebanyak 6 anak yang belum mau terlibat dalam pembelajaran.

Rekapitulasi hasil presentasi rata-rata pada semua aspek yang diamati terdapat 35,28\% dalam kategori Sangat Tinggi, 17,61\% dalam kategori tinggi, 20,28\% dalam kategori Sedang, dan terdapat 26,83\% dalam kategori Rendah.

\section{Tabel 4 Hasil rekapitulasi pengamatan sebelum dan sesudah diberi perlakuan}

\begin{tabular}{|l|l|l|l|}
\hline \multirow{2}{*}{ No } & \multirow{2}{*}{ Kategori } & $\begin{array}{c}\text { Pengamatan } \\
\text { sebelum } \\
\text { perlakuan }\end{array}$ & $\begin{array}{c}\text { Pengamatan } \\
\text { sesudah } \\
\text { perlakuan }\end{array}$ \\
\cline { 3 - 4 } & & Presentase (\%) & Presentase (\%) \\
\hline 1. & Sangat Tinggi (ST) & 0 & 35,28 \\
\hline 2. & Tinggi (T) & 3,33 & 17,61 \\
\hline 3. & Sedang (S) & 13,33 & 20,28 \\
\hline 4. & Rendah (R) & 83,33 & 26,83 \\
\hline & Jumlah & 99,99 & 100 \\
\hline
\end{tabular}

Berdasarkan Tabel 3 hasil rekapitulasi pengamatan sebelum dan setelah diberi perlakuan dalam semua aspek yang diamati yaitu Ketertarikan Anak, Perhatian dalam pembelajaran, dan Keterlibatan anak. Pada kategori Sangat Tinggi (ST) sebelum diberi perlakuan, presentase nya yaitu $0 \%$ dan setelah diberi perlakuan naik menjadi $35,28 \%$, Pada kategori Tinggi (T) sebelum diberi perlakuan, presentase nya yaitu 3,33\% dan setelah diberi perlakuan naik menjadi 17,61\%, selanjutnya pada kategori Sedang (S) sebelum diberi perlakuan, presentase nya yaitu $13,33 \%$ dan setelah diberi perlakuan menjadi 20,28\%, kemudian pada kategori Rendah (S) sebelum diberi perlakuan, presentase nya yaitu $83,33 \%$ dan setelah diberi perlakuan turun menjadi $26,83 \%$, 


\section{1) Aspek Rasa Ingin Tahu Anak}

Apa yang di maksud dengan rasa ingin tahu anak ? rasa ingin tahu anak yaitu berkaitan dengan respon anak terhadap objek (benda,orang,situasi) yang baru, aneh dan asing bagi anak, di sisi lain rasa ingin tahu anak juga dapat di lihat dari ke inginan anak mengeksplorasi,menyelidiki sesuatu objek, orang, benda dan situasi.

Setiap individu memilki rasa ingin tahu dan tidak ada seorang pun yang tidak memiliki rasa ingin tahu sama sekali, seorang anak akan terlihat rasa keingintahuannya di saat ia mulai bertanya hal-hal yang ia lihat,dengar,amati dan sebagainya. Rasa ingin tahu pada individu untuk mengenal lingkungannya sudah terlihat sejak bayi, Bredkamp (1987) mengatakan bahwa bayi dan anak usia dini belajar dengan mengeksperimen lingkungan melalui melihat, mendengar, mencoba, tersenyum dan menggerakan anggota tubuh serta belajar melalui interaksi sosial.

Dari hasil pengamatan awal sebelum diberi perlakuan pada kelompok B TK Dharma Wanita Gedangan, dari 20 anak yang menjadi subjek penelitian minat belajar berdasarkan aspek rasa ingin tahu anak, terdapat 0 anak $(0 \%)$ dalam kategori Sangat Tinggi, ada 1 anak (5\%) kategori Tinggi, 3 anak (15\%) kategori Sedang, dam 16 anak (80\%) kategori Rendah. Melihat hasil pengamatan awal sebelum diberikan perlakuan tersebut, terlihat bahwa rasa ingin tahu anak untuk meningkatkan minat belajar anak masih sangat rendah sehingga perlu diberikan perlakuan untuk meningkatkan minat belajar anak. Pada minggu pertama pada aspek Rasa Ingin Tahu Anak, terdapat 2 anak (10\%) kategori Sangat Tinggi, ada 2 anak (10\%) kategori Tinggi, 4 anak (20\%) kategori Sedang, dan 12 anak (60\%) dalam kategori Rendah.

Melihat hasil pengamatan minggu pertama pada aspek rasa ingin tahu anak, hasil yang di dapat masih kurang baik dan Perlu adanya pengulangan perlakuan. Setelah di lakukan pengulangan hingga pada minggu ke-enam hasil yang di dapatkan yaitu terlihat ada 9 anak (45\%) dalam kategori Sangat Tinggi, 6 anak (30\%) dalam kategori Tinggi, 5 anak (25\%) dalam kategori Sedang dan tidak ada anak (0\%) dalam kategori Rendah. Hal ini membuktikan adanya peningkatan dari minggu pertama sampai minggu ke-enam pada aspek rasa ingin tahu anak di kelompok B TK Dharma Wanita Gedangan. 


\section{2) Aspek Ketertarikan Anak}

Sikap ketertarikan anak dalam belajar merupakan salah satu indikator bahwa anak tersebut memiliki minat belajar yang baik. Hal ini dapat di lihat dari pernyataan Yusuf dan Anwar (dalam Slameto, 2005:31) yg menyatakan bahwa "Minat adalah kecenderungan dalam diri anak didik untuk merasa tertarik pada suatu obyek atau menyenangi sesuatu". 5 Umumnya tanpa adanya minat belajar anak akan menunjukkan sikap yang kurang bersemangat dalam mengikuti materi pembelajaran di kelas.

Minat belajar tersebut muncul di sebabkan oleh beberapa faktor, salah satunya yaitu dengan penggunaan metode pembelajaran yang menyenangkan seperti penggunaan metode eksperimen. Ketertarikan anak dalam proses pembelajaran akan menyebabkan interaksi yang tinggi antara guru dengan anak. Hal ini akan mengakibatkan suasana kelas menjadi kondusif, dimana masing-masing anak dapat melibatkan kemampuannya semaksimal mungkin. Kegiatan pembelajaran yang menarik minat belajar anak, lebih mudah dipelajari, dipahami, dan mampu menambah semangat anak dalam mengikuti kegiatan belajar.

Dari hasil pengamatan awal sebelum diberi tindakan pada kelompok B TK Dharma Wanita Gedangan, dari 20 anak yang menjadi subjek penelitian minat belajar berdasarkan aspek ketertarikan anak, terdapat 0 anak (0\%) dalam kategori Sangat Tinggi, ada 1 anak (5\%) kategori Tinggi, 2 anak (10\%) kategori Sedang, dam 17 anak (85\%) kategori Rendah. Melihat dari hasil pengamatan awal sebelum diberi perlakuan terlihat bahwa rasa ketertarikan anak dalam belajar masih sangat rendah sehingga perlu diberi perlakuan untuk meningkatkan minat belajar anak. Pada minggu pertama pada Aspek Ketertarikan Anak, terdapat 3 anak (15\%) kategori Sangat Tinggi, ada 2 anak (10\%) kategori Tinggi, 2 anak (10\%) kategori Sedang, dan 13 anak (65\%) dalam kategori Rendah

Melihat hasil pengamatan minggu pertama pada aspek ketertarikan anak, hasil yang di dapat masih kurang baik dan Perlu adanya pengulangan perlakuan. Setelah di

${ }^{5}$ Slameto. Belajar dan Faktor yang Mempengaruhinya. (Edisi Revisi. Jakarta : Rineka Cipta) 31 
lakukan pengulangan hingga pada minggu ke-enam hasil yang di dapatkan yaitu terlihat ada 12 anak (60\%) dalam kategori Sangat Tinggi, 6 anak (30\%) dalam kategori Tinggi, 2 anak $(10 \%)$ dalam kategori Sedang dan tidak ada anak (0\%) dalam kategori Rendah. Hal ini membuktikan adanya peningkatan dari minggu pertama sampai minggu ke-enam pada aspek ketertarikan anak dalam belajar di kelompok B TK Dharma Wanita Gedangan.

\section{3) Aspek Keterlibatan Anak}

Keterlibatan siswa bisa diartikan sebagai siswa atau anak berperan aktif sebagai partisipan dalam proses belajar mengajar. Menurut Dimjati dan Mudjiono (1994:56-60), keaktifan siswa dapat didorong oleh peran guru. Guru berupaya untuk memberi kesempatan siswa untuk aktif, baik aktif mencari, memproses dan mengelola perolehan belajarnya. ${ }^{6}$

Untuk dapat meningkatkan keterlibatan siswa dalam proses belajar mengajar guru dapat melakukannya dengan; keterlibatan secara langsung siswa baik secara individual maupun kelompok; penciptaan peluang yang mendorong siswa untuk melakukan eksperimen, upaya mengikutsertakan siswa atau memberi tugas kepada siswa untuk memperoleh informasi dari sumber luar kelas atau sekolah serta upaya melibatkan siswa dalam merangkum atau menyimpulkan pesan pembelajaran dengan adanya kemauan anak untuk terlibat di dalam proses pembelajaran yang di berikan oleh guru, hal ini menandakan bahwa anak tersebut telah memiliki minat belajar di dalam dirinya. Menurut Gie (1998), "minat berarti sibuk, tertarik, atau terlibat sepenuhnya dengan sesuatu kegiatan karena menyadari pentingnya kegiatan itu". ${ }^{7}$ Dengan demikian, minat belajar adalah keterlibatan sepenuhnya seorang siswa dengan segenap kegiatan pikiran secara penuh perhatian untuk memperoleh pengetahuan dan mencapai pemahaman tentang pengetahuan tersebut.

Dari hasil pengamatan awal sebelum diberi perlakuan pada kelompok B TK Dharma Wanita Gedangan, dari 20 anak yang menjadi subjek penelitian minat belajar berdasarkan aspek keterlibatan anak, terdapat 0 anak (0\%) dalam kategori Sangat Tinggi,

\footnotetext{
${ }^{6}$ Dimyati dan Mudjiono. Belajar dan Mengajar. (Jakarta; Rineka Cipta) 56

${ }^{7}$ Gie, The Liang. Cara Belajar yang Efisien. (Yogyakarta: Liberty)
} 
ada 0 anak (0\%) kategori Tinggi, 3 anak (15\%) kategori Sedang, dam 17 anak (85\%) kategori Rendah. Melihat dari hasil pengamatan awal sebelum diberi perlakuan terlihat bahwa rasa keterlibatan anak dalam belajar masih sangat rendah sehingga perlu diberi tindakan untuk diamati. Pada minggu pertama pada Aspek Ketertarikan Anak, terdapat 2 anak (10\%) kategori Sangat Tinggi, ada 2 anak (10\%) kategori Tinggi, 3 anak (15\%) kategori Sedang, dan 13 anak (65\%) dalam kategori Rendah.

Melihat hasil pengamatan minggu pertama pada aspek keterlibatan anak, hasil yang di dapat masih kurang baik dan Perlu adanya pengulangan perlakuan. Setelah di lakukan pengulangan hingga pada minggu ke-enam hasil yang di dapatkan yaitu meningkat menjadi 12 anak (60\%) dalam kategori Sangat Tinggi, 5 anak (25\%) dalam kategori Tinggi, 3 anak (15\%) dalam kategori Sedang dan tidak ada anak (0\%) dalam kategori Rendah. Hal ini membuktikan adanya peningkatan dari minggu pertama sampai minggu ke-enam pada aspek keterlibatan anak dalam belajar di kelompok B TK Dharma Wanita Gedangan.

\section{Penutup}

\section{Kesimpulan}

Berdasarkan hasil penelitian dan pembahasan tentang "pengaruh metode pemberian tugas (take home) terhadap minat belajar anak di kelompok B TK Dharma Wanita Gedangan Mojokerto", maka dapat disimpulkan bahwa ada pengaruh penggunaan metode pemberian tugas (Take Home) terhadap minat belajar anak di kelompok B TK Dharma Wanita Gedangan Mojokerto. Hal ini dapat dilihat pada rekapitulasi hasil penelitian sebelum dan setelah diberikan perlakuan, dalam semua aspek yang diamati yaitu aspek rasa ingin tahu, aspek ketertarikan anak, dan aspek keterlibatan anak diperoleh hasil bahwa pada kategori Sangat Tinggi (ST) sebelum diberi perlakuan, presentase nya yaitu 0\% dan setelah diberi perlakuan naik menjadi 35,28\%, Pada kategori Tinggi (T) sebelum diberi perlakuan, presentase nya yaitu 3,33\% dan setelah diberi perlakuan naik menjadi $17,61 \%$, selanjutnya pada kategori Sedang (S) sebelum diberi perlakuan, presentase nya yaitu $13,33 \%$ dan setelah diberi perlakuan menjadi $20,28 \%$, kemudian pada kategori Rendah (S) sebelum diberi perlakuan, presentase nya yaitu 83,33\% dan setelah diberi perlakuan turun menjadi $26,83 \%$, Sehingga dapat dikatakan bahwa penggunaan metode eksperimen sains sederhana berpengaruh terhadap minat belajar anak. 


\section{Saran}

Berdasarkan hasil penelitian yang telah dilakukan yaitu tentang pengaruh penggunaan metode pemberian tugas (take home) terhadap minat belajar anak maka peneliti mengemukakan beberapa saran sebagai berikut:

1. TK/Yayasan, diharapkan agar dapat selalu memberikan kesempatan bagi para guru untuk melakukan perbaikan pembelajaran dalam upaya meningkatkan kemampuannya sebagai guru yang profesional serta di harapkan dapat menyediakan berbagai macam fasilitas-fasilitas serta media yang dapat menarik minat belajar anak.

2. Guru TK, dalam proses kegiatan pembelajaran di kelas maupun di luar kelas, hendaknya guru TK dapat memberikan kegiatan pembelajaran yang sesuai untuk meningkatkan minat belajar anak, salah satunya adalah dengan melalui penggunaan metode eksperimen sains sederhana.

3. Anak, agar anak selalu aktif dalam kegiatan di kelas maupun di luar kelas. Serta memanfaatkan semua fasilitas yang ada untuk mengembangkan semua potensi yang dimilikinya terutama untuk menjadi anak berkarakter.

4. Peneliti lain, dapat menjadikan hasil penelitian ini sebagai bahan acuan atau pertimbangan dalam merancang penelitian yang sama atau berbeda baik masalah, metode, teknik pengumpulan data, maupun analisisnya.

\section{DAFTAR PUSTAKA}

Dalyono. (2005). Belajar dan Faktor-Faktor yang Mempengaruhinya. Jakarta: PT Rineka Cipta

Dimyati dan Mudjiono. 1994. Belajar dan Mengajar. Jakarta; Rineka Cipta.

Gie, The Liang. 1998. Cara Belajar yang Efisien. Yogyakarta: Liberty.

Muijs, Daniel, \& Reynolds, David. (2008). Effective teaching: Teori dan Aplikasi. Yogyakarta: Pustaka Pelajar.

Slameto, (2005).Belajar dan Faktor yang Mempengaruhinya. Edisi Revisi. Jakarta : Rineka Cipta

Sugihartono, dkk. (2012). Psikologi Pendidikan. Yogyakarta: UNY Press

Sugiyono. (2009). Metode Penelitian Pendidikan Pendekatan Kuantitati, Kualitatif, dan R\&D. Bandung: Alfabeta

Suprijanto. (2007). Pendidikan Orang Dewasa: Dari Teori Hingga Aplikasi. Jakarta: PT Bumi Aksara 